\title{
Development of PCR-based methods for detection of Sphaerothecum destruens in fish tissues
}

\author{
Holly L. Mendonca, Kristen D. Arkush* \\ University of California-Davis, Bodega Marine Laboratory, PO Box 247, 2099 Westside Road, Bodega Bay, \\ California 94923, USA
}

\begin{abstract}
Single-round and nested polymerase chain reaction (PCR) tests were developed for amplification of a $434 \mathrm{bp}$ fragment of the small subunit ribosomal RNA (18S rRNA) gene from Sphaerothecum destruens, previously known as the rosette agent, an intracellular parasite of salmonid fishes. Both tests have successfully amplified $S$. destruens-specific DNA from different isolates of $S$. destruens but not from related organisms. The limits of detection using the nested PCR test were $1 \mathrm{pg}$ for purified $S$. destruens genomic DNA and $0.1 \mathrm{fg}$ for plasmid DNA. We conducted 2 experimental transmission studies, consisting of injection or waterborne exposure of juvenile winterrun Chinook salmon Oncorhynchus tshawytscha to spore stages of the parasite. In the injection study, parasite DNA was detected in $100 \%$ of kidney samples from exposed fish $(n=83)$ at 1 and 3 mo postexposure using nested PCR, versus $98 \%$ using microscopic analysis of Gram-stained impression smears made from the kidney. Following waterborne exposure, fish were sampled over the course of a year. From each fish, samples of gill, liver, posterior intestine and kidney were analyzed. S. destruens-specific DNA was detected most often in gill and kidney over the course of the experiment, and $71 \%(64 / 90)$ of the exposed fish were identified as positive for $S$. destruens using the nested PCR test, versus $16 \%$ (14/90) using microscopic analysis of Gram-stained kidney smears. Natural infections in captive broodstock of adult winter-run Chinook salmon, originally diagnosed by examination of Gram-stained kidney smears, were confirmed using the nested PCR test in all fish examined (15/15). Further, the nested test amplified parasite-specific DNA from other tissues in these fish with varying frequencies. This report introduces the first DNA-based detection method for $S$. destruens, to be used alone as a diagnostic tool or in conjunction with histologic tests for confirmatory identification of the parasite.
\end{abstract}

KEY WORDS: Sphaerothecum destruens - Rosette agent · Polymerase chain reaction · Salmonids · Detection method

Resale or republication not permitted without written consent of the publisher

\section{INTRODUCTION}

Sphaerothecum destruens, previously known as the rosette agent (Arkush et al. 2003), is an intracellular parasite that has been documented as a cause of disease and subsequent mortality in salmonid fishes (Harrell et al. 1986, Hedrick et al. 1989, Arkush et al. 1998). Recently, the organism was shown to have an extracellular motile zoospore stage (Arkush et al. 2003). In vitro cultures of $S$. destruens in the Chinook salmon embryo cell line CHSE-214 (Lannan et al. 1984) have been established (Arkush et al. 1998) and are available from the American Type Culture Collection (ATCC 50643).
The parasite can be experimentally transmitted to both salmon and trout species and the disease and resultant mortality are consistent with naturally occurring infection (Arkush et al. 1998). S. destruens has been detected in cultured populations of salmonid fishes (Harrell et al. 1986, Hedrick et al. 1989, Arkush et al. 1998) but the incidence of the parasite in wild populations is not known.

If present, gross pathological signs in Chinook salmon reflect 1 of 2 forms of the disease: (1) a limited form with nodules often present in the liver, kidney, spleen, heart and mesentery surrounding the intestinal tract and between the pyloric cecae; or (2) a dissemi- 
nated form characterized by enlargement and pallor of the liver, kidney and spleen (Harrell et al. 1986, Hedrick et al. 1989, Arkush et al. 1998). Current methods for the detection of Sphaerothecum destruens include microscopic examination of stained impression smears or histologic sections prepared from affected organs (Harrell et al. 1986, Arkush et al. 1998). These methods can be problematic because they do not provide enough discriminatory detail to definitively differentiate $S$. destruens from related organisms. An alternative DNA-based method to be used as a confirmatory test would therefore be of value. Diagnostic tests using the polymerase chain reaction (PCR) for detection of other fish pathogens have been developed (Andree et al. 1998, Chase \& Pascho 1998, Palenzuela et al. 1999, Gonzalez et al. 2003, Grizzle et al. 2003). These studies report that PCR-based methods surpass the detection limits of the conventional diagnostic methods, especially when testing subclinically infected fishes (Andree et al. 1998, Grizzle et al. 2003). Additionally, PCR-based methods may be used to analyze samples collected from live fish (Smith 2002), while histologic evaluation for detection of this parasite typically requires lethal sampling.

This report describes single-round and nested PCR tests that amplify a portion of the small subunit ribosomal RNA (18S rRNA) gene from Sphaerothecum destruens. Genomic DNA from $S$. destruens spores isolated from different sources, and genomic DNA from organisms related to $S$. destruens were analyzed using S. destruens-specific primers in the PCR tests. The limits of detection for the PCR tests were determined by analyzing serial dilutions of genomic and plasmid $S$. destruens DNA, respectively. Further validation was achieved in side-by-side comparisons of the PCR tests with microscopic evaluation of tissues from experimentally and naturally infected salmon Oncorhynchus tshawytscha. Following a simulated natural exposure (waterborne immersion), we report here on the distribution of $S$. destruens in juvenile salmonids as detected by PCR, providing insight into early attachment of the parasite and the progression of infection.

\section{MATERIALS AND METHODS}

Sources of parasite, spore purification and DNA extraction. Sphaerothecum destruens spores were cultured, collected and purified as previously described (Arkush et al. 2003) from Chinook salmon embryo (CHSE-214) cell cultures (Lannan et al. 1984) separately infected with isolates originally obtained from winter-run Chinook salmon Oncorhynchus tshawytscha in Bodega Bay, California (Arkush et al. 1998) and Manchester, Washington (Harrell et al. 1986), and
1 isolate obtained from Atlantic salmon (Salmo salar) in Santa Cruz, California (Hedrick et al. 1989). Spores from the Bodega Bay Sphaerothecum destruens isolate were induced to enter the zoospore stage by introduction to freshwater as described by Arkush et al. (2003). Cell culture-derived $S$. destruens spores and zoospores were pelleted separately by centrifugation $(208 \times g$, $5 \mathrm{~min}$ ) and DNA was extracted using the DNeasy ${ }^{\mathrm{TM}}$ Tissue Kit (Qiagen) and quantified (Arkush et al. 2003). To determine extraction efficiency, purified $S$. destruens spores were counted and suspended in sterile water to a final concentration of $10^{8} \mathrm{ml}^{-1}$. Serial 10-fold dilutions of spores ( $50 \mu$ l total volume) were extracted, as described by Arkush et al. (2003), and nonquantified DNA (5 $\mu$ l of eluate) was used as template in single-round and nested PCR assays.

PCR primer selection. Sequences from the $18 \mathrm{~S}$ rRNA gene were obtained from GenBank for the following organisms (accession numbers in parentheses): Dermocystidium salmonis (U21337), Dermocystidium spp. (U21336), Ichthyophonus hoferi (U25637) and Psorospermium haeckeli (U33180). Sequences were manually aligned with the 18S rRNA gene sequence (L29455) of the rosette agent Sphaerothecum destruens using the program Mac DNAsis (Version 2.0, Miraibio). Primers for single-round and nested PCR tests were derived from the most unique regions of the $S$. destruens $18 \mathrm{~S}$ rRNA gene sequence as compared to the related organisms. The first round of the nested PCR test amplified a 550 bp segment of the 18S rRNA gene with primers derived from Nucleotides 185 to 750 ; the sequence for the forward primer (Sd-1F) was 5'-CGACTTTTCGGAAGGGATGTATT-3', and for the reverse primer (Sd-1R) 5'-AGTCCCAAACTCGACGCACACT-3'. The single-round assay and the second round of the nested assay amplified a 434 bp segment of the 18S rRNA gene with primers derived from Nucleotides 236 to 683 ; the sequence for the forward primer (Sd-2F) was 5'-CCCTCGGTTTCTTGGTGATTCATAATAACT-3', and for the reverse primer (Sd-2R) 5'-CTCGTCGGGGCAAACACCTC-3'. Primers were designed using the OLIGO software package (NBI) and were synthesized by Integrated DNA Technologies (IDT).

PCR and sequencing. PCR assays were conducted in a PTC-200 DNA Engine thermal cycler (M. J. Research). Single-round reactions were typically $30 \mu \mathrm{l}$, consisting of $5 \mu \mathrm{l}$ of template and used the secondround primer pair and the second-round PCR amplification conditions. Nested PCR reactions were typically 30 to $50 \mu \mathrm{l}$ using first-round primers and 5-10 $\mu \mathrm{l}$ template, and then $0.5 \mu \mathrm{l}$ of the first round reaction was used as the template in a $20 \mu \mathrm{l}$ second-round reaction with second-round primers. PCR reactions were performed in $1 \times$ Taq polymerase reaction buffer 
(Promega) with $1.5 \mathrm{mM} \mathrm{MgCl}, 0.2 \mathrm{mM}$ each dNTP, $0.3 \mu \mathrm{M}$ each primer for first or second/single-round and $0.03 \mathrm{U}$ Taq DNA polymerase (Promega). Optimal cycling conditions were: an initial denaturation of 5 min at $95^{\circ} \mathrm{C}$, then 25 cycles (first round) or 35 cycles (second or single round) of $30 \mathrm{~s}$ at $95^{\circ} \mathrm{C}$, followed by $30 \mathrm{~s}$ at $65^{\circ} \mathrm{C}$, followed by $30 \mathrm{~s}$ at $72^{\circ} \mathrm{C}$. A final elongation step of 7 min at $72^{\circ} \mathrm{C}$ was included. PCR products were electrophoresed on $1.5 \%$ agarose gels and the gels were stained with ethidium bromide. Figs. 1 \& 2 were generated with a digital camera and transilluminator (Epi Chemi II Darkroom, UVP Laboratory Products) using Labworks Software, Version 4. Controls for each PCR assay included: (1) a positive control with $50 \mathrm{ng}$ purified genomic Sphaerothecum destruens DNA from cell culture, and (2) a negative control with no DNA template added. PCR products from amplification of $100 \mathrm{ng}$ of cell culture-purified S. destruens genomic DNA used in the single-round reaction were purified using a PCR purification kit (Promega) and sequenced at the University of California, Division of Biological Sciences DNA sequencing facility (Davis).

Testing related organisms. We analyzed 2 related (within the class Mesomycetozoea) salmonid parasites, Ichthyophonus hoferi and Dermocystidium salmonis, using the Sphaerothecum destruens-specific primers in the PCR tests. Cultures of I. hoferi, originally isolated from Chinook salmon from the Yukon River, village of Emmonak, Alaska, were fixed in 95\% ethanol, and then washed with sterile water; DNA was extracted from the pelleted spores as described for $S$. destruens. D. salmonis cysts were obtained from frozen $\left(-20^{\circ} \mathrm{C}\right)$ infected gill tissues from spring-run Chinook salmon collected from the Trask Hatchery, Tillamook, Oregon, and DNA was extracted from the gill tissue as described in the subsection 'Processing of fish tissues'.

Limits of detection. The Sphaerothecum destruens 18S rRNA gene sequence was cloned into the $3957 \mathrm{bp}$ plasmid vector, $\mathrm{pCR}^{\circledR} 4$-TOPO ${ }^{\circledR}$ using the TOPO TA Cloning $^{\circledast}$ Kit for Sequencing (Version F, Invitrogen) according to the manufacturer's protocols. The $S$. destruens sequence used in the cloning was amplified from the Bodega Bay isolate (100 ng) using the firstround PCR reaction conditions, except that 30 cycles were performed and the annealing step was $60^{\circ} \mathrm{C}$ for $1 \mathrm{~min}$. PCR products used in the cloning were purified using the Wizard@ PCR Prep DNA Purification System (Promega) and quantified using a spectrophotometer. Transformants resulting from this cloning procedure were grown on Luria broth agar plates containing $50 \mu \mathrm{g} \mathrm{ml}^{-1}$ kanamycin (Sigma), and individual colonies were tested in single-round PCR tests $(20 \mu \mathrm{ll})$ as described in the third subsection above, except that the initial denaturation step was increased to $10 \mathrm{~min}$ at $94^{\circ} \mathrm{C}$ and 30 cycles were performed with the annealing step at $55^{\circ} \mathrm{C}$ for $1 \mathrm{~min}$. Primers used were the forward TOPO TA Cloning ${ }^{\circledR}$ Kit primer (T3) with the reverse second-round primer (Sd-2R). Selected positive colonies were subjected to DNA extraction using the Wizard ${ }^{\circledR}$ Plus Minipreps DNA purification system (Promega).

To determine the limits of detection for the PCR assay, genomic DNA of Sphaerothecum destruens spores derived from cell cultures (Bodega Bay isolate) and $S$. destruens plasmid DNA were each diluted to $50 \mathrm{ng}^{-1} \mathrm{l}^{-1}$ in sterile water, then serial 10-fold dilutions were made in sterile water to $0.05 \mathrm{fg}^{-1}{ }^{-1}$ for the genomic DNA dilutions and to $0.0005 \mathrm{fg}^{-1} \mathrm{l}^{-1}$ for the plasmid DNA dilutions. We used $2 \mu \mathrm{l}$ of each dilution in single-round or nested PCR tests (30 $\mu$ l total volume), with or without $300 \mathrm{ng}$ uninfected Chinook salmon DNA added to each dilution, to determine if host DNA interfered with the PCR tests.

Fish source. Progeny of captive broodstock of Sacramento River, winter-run Oncorhynchus tshawytscha were used for the in vivo experiments with Sphaerothecum destruens. Adult broodstock fish with no prior history of $S$. destruens exposure were spawned at the University of California, Bodega Marine Laboratory (BML), Bodega Bay, in the late summer of 2001. Offspring were reared as described by Arkush et al. (2002). Prior to the experiment, some of these fish were transferred to $56.7 \mathrm{l}$ tanks in a pathogen-containment laboratory at BML. Fish were approximately 6 to $10 \mathrm{mo}$ old at the time of the challenges.

Tissue samples were also obtained during necropsies of adult captive broodstock of Sacramento River, winter-run Chinook salmon. Fish were 3 to 4 yr old at the time of death. These fish originated from stocks that had been naturally exposed to the parasite and subsequently transferred to BML where they were reared in both freshwater and seawater from 1992 to 1995 as described by Arkush et al. (1998).

Experimental infection of juvenile fish by injection of parasite spores. Sphaerothecum destruens spores derived from cell cultures (Bodega Bay isolate) were purified and suspended to a concentration of $9.8 \times$ $10^{7}$ spores $\mathrm{ml}^{-1}$ in cell culture media as described by Arkush et al. (1998). In each of 2 replicate tanks, 60 fish received $0.1 \mathrm{ml}$ of the $S$. destruens spore suspension via intraperitoneal (i.p.) injection. In a separate tank, 50 fish each received $0.1 \mathrm{ml}$ of cell culture media via i.p. injection as a treatment control.

At 1 mo post-injection, 12 control fish and 30 exposed fish were removed from the tanks and euthanized with an overdose of methane tricaine sulfonate (MS-222, Argent Chemical Laboratories) at a concentration of $500 \mathrm{mg} \mathrm{l}^{-1}$. At 3 mo post-injection, 20 control fish and 53 exposed fish were collected and euthanized. All 
sampled fish were weighed, measured and then frozen at $-70^{\circ} \mathrm{C}$. Whole blood was collected from a subsample of fish at both time points and stored at $-70^{\circ} \mathrm{C}$.

Experimental infection of juvenile fish by immersion in water containing parasite spores. Fish were divided into 4 replicate $56.7 \mathrm{l}$ tanks each containing 100 fish. Prior to each exposure, the water level was lowered to approximately $8 l$, as a static system with aeration. Exposures to Sphaerothecum destruens spores were performed every $3 \mathrm{~d}$ for a total of 3 times. Parasite spores derived from cell cultures (Bodega Bay isolate) were purified as described by Arkush et al. (1998), suspended in distilled water, and added to each of 2 tanks at each exposure period to achieve average final concentrations in each tank of $8.6 \times 10^{4}$ spores $\mathrm{ml}^{-1}\left(6.9 \times 10^{6}\right.$ spores fish $\left.^{-1}\right)$. To each of the 2 remaining tanks, distilled water alone was added. The exposures were maintained for $4 \mathrm{~h}$, then water flow was restored $\left(1 \mathrm{l} \mathrm{h}^{-1}\right)$. The end of the third exposure was considered as Time 0 . We removed 5 fish per replicate tank at $1,7,14,28$ and $42 \mathrm{~d}$, and at 2, 3, 6 and 12 mo postexposure (p.e.). These fish were euthanized as described earlier, and then weighed, measured and frozen at $-70^{\circ} \mathrm{C}$ for later analysis.

Processing of fish tissues. Tissues collected from sampled experimental fish or natural mortalities from the adult broodstock varied, depending on the experiment, and included some or all of the following: gill, liver, posterior intestine, spleen, gonad, heart and kidney. Whole blood was collected from a subsample of fish from the injection experiment. Kidney tissue from each fish was divided for use in PCR analysis and impression smears. DNA was extracted from each tissue separately ( $25 \mathrm{mg}$ each, rodent tail protocol) and from whole blood (10 $\mu \mathrm{l}$, whole nucleated blood protocol) using the DNeasy ${ }^{\mathrm{TM}}$ Tissue Kit (Qiagen). DNA solutions were quantified in a spectrophotometer at $260 \mathrm{~nm}$ and stored at $-20^{\circ} \mathrm{C}$.

Single-round and nested Sphaerothecum destruensspecific PCR assays were performed in triplicate on 200 to $300 \mathrm{ng}$ of template (total DNA). PCR products were electrophoresed on agarose gels (as described in earlier subsection 'PCR and sequencing') and a sample was scored positive if it was positive in any of the triplicate reactions. For sampled fish from the immersion experiment and the adult broodstock natural mortalities, individual fish scores (IFS) were assigned to each fish based on the independent PCR scores from different organs, and a fish was scored as positive if $S$. destruens-specific DNA was amplified from any of the organs in any of the triplicate PCR reactions. The DNA quality of each tissue sample was tested using PCR amplification of a portion (257 bp) of the major histocompatibility $(\mathrm{MhC})$ gene (Class II B1 exon) from Sacramento River Chinook salmon (Miller et al. 1997) either as an internal standard in single- or secondround reactions by adding $0.5 \mu \mathrm{M} M h c$ primers to the reaction mix (in addition to $S$. destruens primers) or as a separate reaction using PCR conditions as previously described by Arkush et al. (2002). Only tissue samples showing Mhc-specific PCR product were included in the analysis.

Impression smears from kidney tissues were fixed, Gram-stained and evaluated as described by Harrell et al. (1986), and Arkush et al. (1998). Presumptive diagnoses of Sphaerothecum destruens infections in these fish were made based on a scoring system that correlated severity of infection with a range from 0 to 4 as follows: (0) = uninfected: no $S$. destruens spores seen per 10 imprints at $100 \times$ magnification; $(1)=$ very low infection: 1 to 10 spores per 10 imprints at $100 \times$ magnification $_{i}(2)=$ low infection: 1 to 3 spores per $100 \times$ field; (3) = moderately high infection: 3 to 10 spores per $100 \times$ field $_{i}(4)=$ high infection: $>10$ spores per $100 \times$ field.

\section{RESULTS}

\section{PCR analysis of Sphaerothecum destruens and related organisms}

The sequenced products from the single-round PCR agreed with the published 18S rRNA gene sequence for the rosette agent (Kerk et al. 1995; Sphaerothecum destruens). The single-round PCR assay was sufficient for amplification of purified DNA from spores of 3 different isolates of $S$. destruens as well as the zoospore stage (Fig. 1A). Single-round and nested PCR tests using $S$. destruens-specific primers and DNA from Ichthyophonus hoferi, Dermocystidium salmonis, or the no template control produced no PCR product (Fig. 1A, B).

\section{Limits of detection}

Using serial dilutions of purified parasite genomic DNA, the limit of detection using the nested PCR was 1 pg (Fig. 2A), for the single-round test it was $10 \mathrm{pg}$ (data not shown). Using serial dilutions of purified plasmid containing parasite DNA, as little as $0.1 \mathrm{fg}$ DNA was detected using the nested PCR (Fig. 2B), while the single-round detected $1 \mathrm{fg}$ (data not shown). Addition of $300 \mathrm{ng}$ fish DNA prior to amplification in single-round or nested PCR on serial dilutions of genomic or plasmid parasite DNA did not affect the detection thresholds of the PCR assays (data not shown). DNA extraction efficiency, as determined by spore dilution, was limited to a minimum of 10 spores using the Qiagen extraction method (data not shown). 


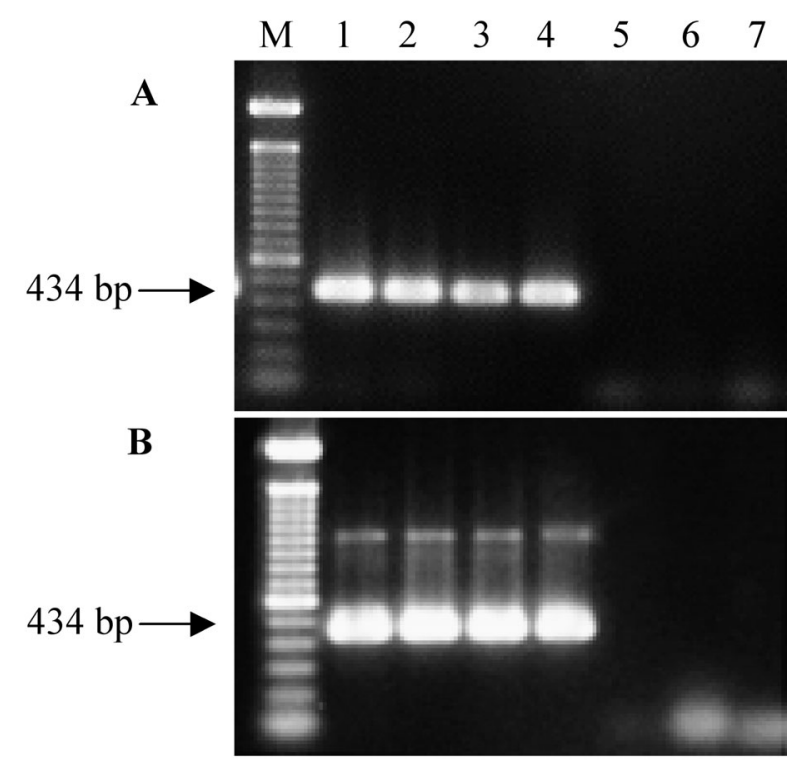

Fig. 1. Sphaerothecum destruens and related organisms in (A) single-round and (B) nested PCR using $S$. destruens-specific primers. Lanes 1 to 3 are $S$. destruens-specific PCR products from 100 ng of DNA from cell culture-derived spore stages of different isolates; Lane 1: Chinook salmon Oncorhynchus tshawytscha from Bodega Bay, CA; Lane 2: Atlantic salmon Salmo salar from Santa Cruz, CA; Lane 3: Chinook salmon from Manchester, WA; Lane 4: S. destruens-specific PCR product from $100 \mathrm{ng}$ of DNA from Bodega Bay isolate after zoosporulation; Lanes 5, 6: S. destruens-specific PCR on 300 ng DNA from Dermocystidium salmonis-infected gill tissue (from Chinook salmon, Tillamook, OR) and $300 \mathrm{ng}$ Ichthyophonus hoferi DNA (originally isolated from Chinook salmon from Emmonak, AK), respectively; Lane 7: no template control; Lane M: 100 bp DNA ladder

A

$$
\begin{array}{lllllllllll}
\mathrm{M} & 1 & 2 & 3 & 4 & 5 & 6 & 7 & 8 & 9 & 10
\end{array}
$$

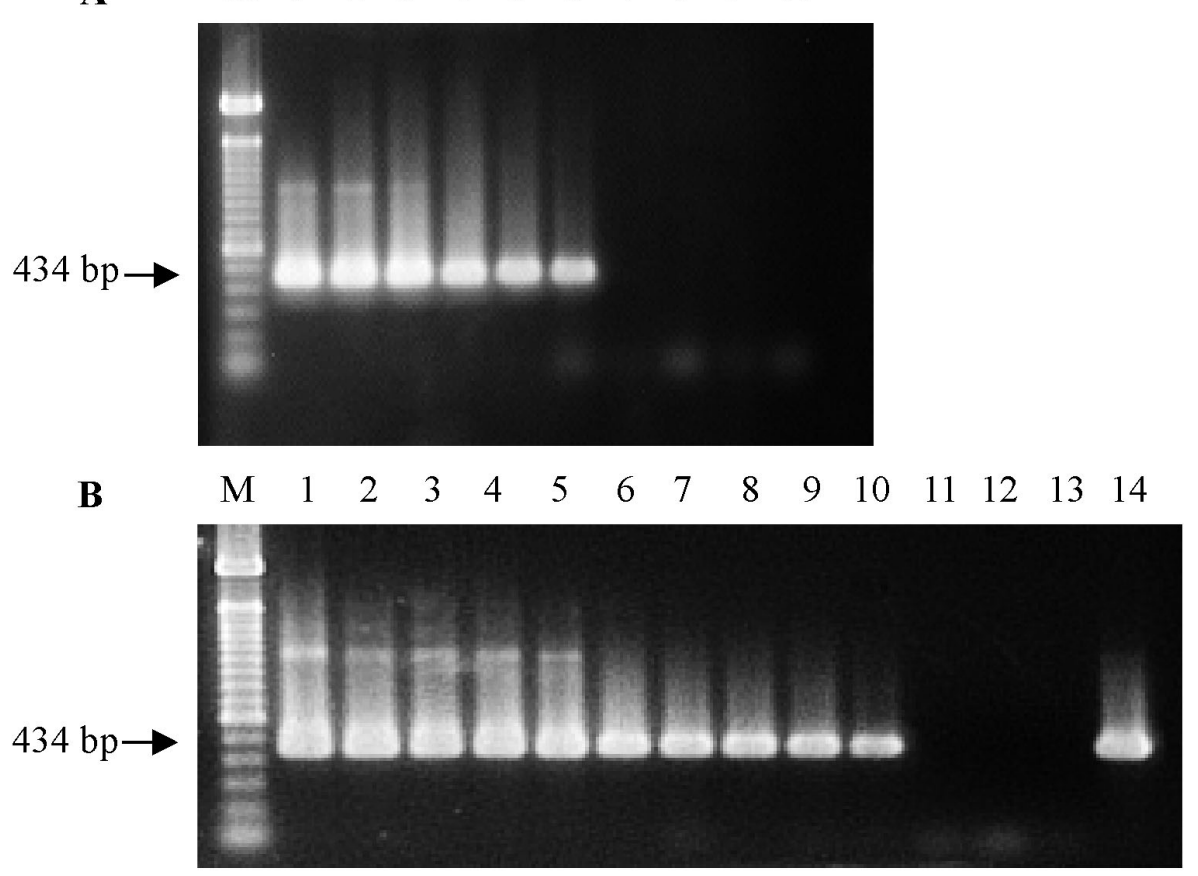

When the starting template for the nested PCR was $>1 \mathrm{ng}$ of purified genomic or plasmid Sphaerothecum destruens DNA, other products were often visible on the ethidium bromide-stained gel. These fragments included the residual first-round product (550 bp) and a faint product between 1000 and 1100 bp (Figs. 1B \& 2B). Production of these additional products did not interfere with production of the $S$. destruens-specific second-round 434 bp product, and they were usually not present following nested PCR on infected fish tissue or on purified genomic DNA at $<1 \mathrm{ng}$ template.

\section{Experimental infection of juvenile fish by injection of parasite spores}

No clinical signs were observed in sampled fish. Average weights of sampled fish at 1 and 3 mo were $15.5 \pm 5.3 \mathrm{~g}$ and $35.4 \pm 13.7 \mathrm{~g}$, respectively. Using the nested and single-round PCR assays, 100\% (83/83) and $95 \%(79 / 83)$ of kidney samples from all experimentally exposed fish (1 mo plus 3 mo samples) tested positive for Sphaerothecum destruens, respectively (Table 1). Detection in whole blood from a subsample (37/83 exposed fish) was less frequent: $32 \%(12 / 37)$ of blood samples over both time points tested positive using the nested PCR assay versus $3 \%$ (1/37) using single-round PCR (Table 1). No parasite-specific DNA was detected in kidney $(\mathrm{n}=32)$ or blood $(\mathrm{n}=15)$ collected from control fish (data not shown) at either time point. Spores of $S$. destruens were identified in Gram-
Fig. 2. Sphaerothecum destruens. Threshold of detection by nested PCR on serial dilutions of purified (A) cell culture-derived genomic or (B) plasmid $S$. destruens DNA. (A) Lanes 1 to 9 are PCR products from $100 \mathrm{ng}$, $10 \mathrm{ng}, 1 \mathrm{ng}, 0.1 \mathrm{ng}, 10 \mathrm{pg}, 1 \mathrm{pg}, 0.1 \mathrm{pg}$, $10 \mathrm{fg}$ and $1 \mathrm{fg}$, respectively; Lane 10 : no template control. (B) Lanes 1 to 12 are PCR products from $100 \mathrm{ng}, 10 \mathrm{ng}$, $1 \mathrm{ng}, 0.1 \mathrm{ng}, 10 \mathrm{pg}, 1 \mathrm{pg}, 0.1 \mathrm{pg}, 10 \mathrm{fg}$, $1 \mathrm{fg}, 0.1 \mathrm{fg}, 0.01 \mathrm{fg}$ and $0.001 \mathrm{fg}$, respectively; Lane 13: no template control; Lane 14: positive control containing $50 \mathrm{ng}$ purified genomic $S$. destruens DNA. Lanes M: 100 bp DNA ladder 
Table 1. Sphaerothecum destruens. Detection in kidney and blood of experimentally infected juvenile Oncorhynchus tshawytscha by injection at 1 and 3 mo post-exposure using single-round (SR) and nested (N) PCR, and microscopic evaluation of Gram-stained impression smears from kidney (Gram). Gram scores 0 to 4 correlate with severity of infection $(0=$ uninfected, $4=$ highly infected; see last subsection of 'Materials and methods' for scoring system). n: number of samples

\begin{tabular}{|c|c|c|c|c|c|c|c|c|c|c|c|}
\hline \multirow[t]{2}{*}{ Time } & \multicolumn{3}{|c|}{ Kidney } & \multicolumn{3}{|c|}{ Blood } & \multicolumn{5}{|c|}{ Gram score } \\
\hline & $\mathrm{n}$ & SR & $\mathrm{N}$ & $\mathrm{n}$ & SR & $\mathrm{N}$ & 0 & 1 & 2 & 3 & 4 \\
\hline $1 \mathrm{mo}$ & 30 & 29 & 30 & 15 & 1 & 7 & 2 & 27 & 1 & 0 & 0 \\
\hline $3 \mathrm{mo}$ & 53 & 50 & 53 & 22 & 0 & 5 & 0 & 41 & 10 & 2 & 0 \\
\hline Total & 83 & 79 & 83 & 37 & 1 & 12 & 2 & 68 & 11 & 2 & 0 \\
\hline
\end{tabular}

stained impression smears of kidney tissues from $98 \%$ (81/83) of exposed fish sampled over both time points (Table 1), but not in stained impression smears from control fish (data not shown).

\section{Experimental infection of juvenile fish by immersion in water containing parasite spores}

No mortalities or clinical signs were observed in any fish over the course of the experiment. The average weight of sampled fish at $1 \mathrm{~d}$ p.e. was $3.5 \pm 0.7 \mathrm{~g}$ and at the end of the experiment (12 mo) was $60.8 \pm$ $22.8 \mathrm{~g}$. A total of 90 exposed fish were sampled. We collected 4 organs per fish (gill, liver, posterior intestine, and kidney) resulting in 360 individual samples tested. The nested PCR test detected Sphaerothecum destruens-specific DNA in 108 of these 360 samples (Table 2). The single-round test resulted in 57 positive samples, with 42 of these in agreement with the nested assay (15 positive samples unique to the single-round PCR test, Table 2). In comparisons of single-round and nested PCR tests to determine individual fish scores (IFS), the nested test identified $S$. destruens-specific DNA in 64 of 90 (71\%) exposed fish (Table 2) while single-round PCR identified 38 positive fish $(42 \%$, Table 2$)$, all of which were also identified using the nested assay. All tissues from control fish were negative for $S$. destruens using single-round or nested PCR (data not shown).

At 1 d p.e., parasite-specific DNA was amplified in $50 \%$ of the posterior intestine and $10 \%$ of the kidney samples, but was not detected in any organ at $7 \mathrm{~d}$ p.e. (Table 2). Sphaerothecum destruens-specific DNA was detected in 20 to $90 \%$ of gill samples at $14 \mathrm{~d}$ to $12 \mathrm{mo}$ p.e., with a total of 42 positive from 90 exposed fish (47\%, Table 2). Similarly, parasite-specific DNA was detected in 10 to $100 \%$ of kidney samples at sampling times from $1 \mathrm{~d}$ to 12 mo p.e., with a total of 43 positive from 90 exposed fish (48\%, Table 2). Detection of the parasite was less frequent in the posterior intestine and liver; frequencies ranged from 0 to $50 \%$ and 0 to $30 \%$, respectively, with totals of 16 positive intestine (18\%) and 7 positive liver ( $8 \%$ ) samples from the 90 exposed fish sampled (Table 2).

The presence of the parasite was confirmed in some of the PCR-positive fish using microscopic analysis of Gram-stained impression smears from the kidney: $50 \%$ of sampled exposed fish at 6 mo and $90 \%$ at 12 mo p.e. (Table 2). The parasite was not detected by this method in any fish sampled before 6 mo p.e. Detection of the parasite from all exposed fish based on this method was $16 \%(14 / 90)$ compared to $48 \%$ (43/90) using the nested PCR test on DNA purified from kidney samples (Table 2).

\section{Detection of Sphaerothecum destruens in naturally exposed adult fish}

Broodstock of naturally exposed, adult, winter-run Chinook salmon $(n=20)$ showed a range of responses, from no abnormalities to moderate internal clinical signs (Arkush et al. 1998) at necropsy (data not shown). Microscopic examination of Gram-stained impression smears of kidney from these fish showed a range of infection, from uninfected $(n=5)$ to low $(n=7)$ and highly ( $\mathrm{n}=8$ ) infected, and samples chosen for the PCR analysis were selected to reflect this range. Sphaerothecum destruens-specific DNA was detected in tissues from infected fish $(\mathrm{n}=15)$ with the following frequencies using the nested and single-round tests, respectively: $100 \%(15 / 15)$ and $60 \%(9 / 15)$ of kidney samples; $93 \%$ $(14 / 15)$ and $87 \%(13 / 15)$ of posterior intestine samples; $93 \%(14 / 15)$ and $73 \%(11 / 15)$ of liver samples; $80 \%$ $(12 / 15)$ and $73 \%(11 / 15)$ of gill samples; $80 \%(12 / 15)$ and $73 \%(11 / 15)$ of spleen samples; $60 \%(9 / 15)$ and $33 \%(5 / 15)$ of gonad samples; $60 \%(9 / 15)$ and $40 \%$ $(6 / 15)$ of heart samples (Table 3$)$. These fish were confirmed as $S$. destruens-positive in 15 of 15 cases (100\%) using nested PCR and in 14 of 15 cases (93\%) using single-round PCR based on individual fish scores (IFS). Fish that were negative for $S$. destruens based on Gram-stain score for kidney impression smears were included in the analysis $(\mathrm{n}=5)$ and produced no PCR product for the kidney; however, the liver and posterior intestine were positive for 1 fish (Table 3). 
Table 2. Oncorhynchus tshawytscha. Detection of Sphaerothecum destruens using nested PCR in gill (G), liver (L), posterior intestine (I) and kidney (K) from individual juvenile fish following immersion exposure to parasite spores from $1 \mathrm{~d}$ to $12 \mathrm{mo}$ postexposure. Individual fish scores (IFS) are given for each fish. Values in parentheses: single-round PCR results for each organ and IFS; GR: scores from microscopic evaluation of Gram-stained impression smears from kidney; negative PCR or Gram-scores are left blank. T: total $S$. destruens-positive samples for each organ or IFS; overall totals are given at bottom of table. (See last subsection of 'Materials and methods' for scoring systems)

\begin{tabular}{|c|c|c|c|c|c|c|c|c|c|c|c|c|c|c|c|}
\hline Time & Fish no. & G & $\mathrm{L}$ & I & $\mathrm{K}$ & GR & IFS & Time & Fish no. & G & $\mathrm{L}$ & I & $\mathrm{K}$ & GR & IFS \\
\hline \multirow[t]{11}{*}{$1 \mathrm{~d}$} & 1 & & & & & & $0(0)$ & \multirow[t]{11}{*}{$2 \mathrm{mo}$} & 1 & + & & \multirow[t]{2}{*}{$+(+)$} & \multicolumn{2}{|l|}{$+(+)$} & $+(+)$ \\
\hline & 2 & & & + & + & & $+(0)$ & & 2 & $+(+)$ & & & \multicolumn{2}{|l|}{+} & $+(+)$ \\
\hline & 3 & & & & & & $0(0)$ & & 3 & + & & & \multicolumn{2}{|l|}{+} & $+(0)$ \\
\hline & 4 & & & + & & & $+(0)$ & & 4 & + & & & & & $+(0)$ \\
\hline & 5 & & & & & & $0(0)$ & & 5 & + & & & \multicolumn{2}{|l|}{$+(+)$} & $+(+)$ \\
\hline & 6 & & & & & & $0(0)$ & & 6 & & & & & $0(0)$ \\
\hline & 7 & & & & & & $0(0)$ & & 7 & + & & & & & $+(0)$ \\
\hline & 8 & & & + & & & $+(0)$ & & 8 & + & & & \multicolumn{2}{|l|}{+} & $+(0)$ \\
\hline & 9 & & & $+(+)$ & & & $+(+)$ & & 9 & + & & & & $+(0)$ \\
\hline & 10 & & & + & & & $+(0)$ & & 10 & $+(+)$ & & & \multicolumn{2}{|l|}{+} & $+(+)$ \\
\hline & $\mathbf{T}$ & $0(0)$ & $0(0)$ & $5(1)$ & $1(0)$ & 0 & 5 (1) & & $\mathbf{T}$ & $9(2)$ & $0(0)$ & $1(1)$ & $6(2)$ & 0 & $9(4)$ \\
\hline \multirow[t]{11}{*}{$7 \mathrm{~d}$} & 1 & & & & & & $0(0)$ & \multirow[t]{11}{*}{$3 \mathrm{mo}$} & 1 & $+(+)$ & & & & & $+(+)$ \\
\hline & 2 & & & & & & $0(0)$ & & 2 & + & $(+)$ & & $+(+)$ & & $+(+)$ \\
\hline & 3 & & & & & & $0(0)$ & & 3 & & & & & & $0(0)$ \\
\hline & 4 & & & & & & $0(0)$ & & 4 & + & & + & $+(+)$ & & $+(+)$ \\
\hline & 5 & & & & & & $0(0)$ & & 5 & & & & $+(+)$ & & $+(+)$ \\
\hline & 6 & & & & & & $0(0)$ & & 6 & & & & $+(+)$ & & $+(+)$ \\
\hline & 7 & & & & & & $0(0)$ & & 7 & $+(+)$ & & + & $+(+)$ & & $+(+)$ \\
\hline & 8 & & & & & & $0(0)$ & & 8 & + & & & & & $+(0)$ \\
\hline & 9 & & & & & & $0(0)$ & & 9 & + & & & & & $+(0)$ \\
\hline & 10 & & & & & & $0(0)$ & & 10 & + & & & $+(+)$ & & $+(+)$ \\
\hline & $\mathbf{T}$ & $0(0)$ & $0(0)$ & $0(0)$ & $0(0)$ & 0 & $0(0)$ & & $\mathbf{T}$ & $7(2)$ & 0 (1) & $2(0)$ & $6(6)$ & $\mathbf{0}$ & $9(7)$ \\
\hline $14 \mathrm{~d}$ & 1 & & & & & & $0(0)$ & $6 \mathrm{mo}$ & 1 & & & & + & 1 & $+(0)$ \\
\hline & 2 & & & & & & $0(0)$ & & 2 & & & & + & & $+(0)$ \\
\hline & 3 & & & & & & $0(0)$ & & 3 & & & & & & $0(0)$ \\
\hline & 4 & & & & & & $0(0)$ & & 4 & & & $(+)$ & + & & $+(+)$ \\
\hline & 5 & + & & & & & $+(0)$ & & 5 & & + & & + & 1 & $+(0)$ \\
\hline & 6 & + & & & & & $+(0)$ & & 6 & & & + & $+(+)$ & 1 & $+(+)$ \\
\hline & 7 & & & & + & & $+(0)$ & & 7 & & & & $+(+)$ & 1 & $+(+)$ \\
\hline & 8 & & & & & & $0(0)$ & & 8 & & & + & + & & $+(0)$ \\
\hline & 9 & + & & & & & $+(0)$ & & 9 & + & + & & $+(+)$ & 1 & $+(+)$ \\
\hline & 10 & & & & & & $0(0)$ & & 10 & + & & & + & & $+(0)$ \\
\hline & $\mathbf{T}$ & $3(0)$ & $0(0)$ & $0(0)$ & $1(0)$ & 0 & $4(0)$ & & $\mathbf{T}$ & $2(0)$ & $2(0)$ & $2(1)$ & $9(3)$ & 5 & $9(4)$ \\
\hline $28 \mathrm{~d}$ & 1 & + & & $(+)$ & & & $+(+)$ & $12 \mathrm{mo}$ & 1 & & & & $+(+)$ & 1 & $+(+)$ \\
\hline & 2 & + & $(+)$ & & $(+)$ & & $+(+)$ & & 2 & $+(+)$ & & + & $+(+)$ & 1 & $+(+)$ \\
\hline & 3 & + & & & & & $+(0)$ & & 3 & $+(+)$ & $+(+)$ & $+(+)$ & $+(+)$ & 2 & $+(+)$ \\
\hline & 4 & + & & & & & $+(0)$ & & 4 & & & & $+(+)$ & 1 & $+(+)$ \\
\hline & 5 & & & & & & $0(0)$ & & 5 & + & $+(+)$ & + & $+(+)$ & 2 & $+(+)$ \\
\hline & 6 & + & & & + & & $+(0)$ & & 6 & + & & + & $+(+)$ & 1 & $+(+)$ \\
\hline & 7 & + & + & & $(+)$ & & $+(+)$ & & 7 & + & + & & $+(+)$ & 1 & $+(+)$ \\
\hline & 8 & $+(+)$ & $(+)$ & $(+)$ & $(+)$ & & $+(+)$ & & 8 & & & & + & & $+(0)$ \\
\hline & 9 & & $+(+)$ & & $(+)$ & & $+(+)$ & & 9 & + & & & $+(+)$ & 1 & $+(+)$ \\
\hline & 10 & + & & & + & & $+(0)$ & & 10 & + & & & $+(+)$ & 1 & $+(+)$ \\
\hline & $\mathbf{T}$ & 8 (1) & $2(3)$ & 0 (2) & $2(4)$ & 0 & 9 (5) & & $\mathbf{T}$ & $7(2)$ & $3(2)$ & $4(1)$ & 10 (9) & 9 & 10 (9) \\
\hline $42 \mathrm{~d}$ & 1 & & & & $+(+)$ & & $+(+)$ & Totals & 90 & $42(9)$ & $7(10)$ & $16(7)$ & $43(31)$ & 14 & $64(38)$ \\
\hline & 2 & & $(+)$ & & $+(+)$ & & $+(+)$ & & & & & & & & \\
\hline & 3 & & & + & $+(+)$ & & $+(+)$ & & & & & & & & \\
\hline & 4 & + & & & $+(+)$ & & $+(+)$ & & & & & & & & \\
\hline & 5 & & & & & & $0(0)$ & & & & & & & & \\
\hline & 6 & + & & & + & & $+(0)$ & & & & & & & & \\
\hline & 7 & + & & + & $+(+)$ & & $+(+)$ & & & & & & & & \\
\hline & 8 & $+(+)$ & $(+)$ & & $+(+)$ & & $+(+)$ & & & & & & & & \\
\hline & 9 & + & $(+)$ & & & & $+(+)$ & & & & & & & & \\
\hline & 10 & $+(+)$ & $(+)$ & $(+)$ & $+(+)$ & & $+(+)$ & & & & & & & & \\
\hline & $\mathbf{T}$ & $6(2)$ & $0(4)$ & 2 (1) & $8(7)$ & 0 & $9(8)$ & & & & & & & & \\
\hline
\end{tabular}


Table 3. Oncorhynchus tshawytscha. Detection of Sphaerothecum destruens in tissues from captive broodstock of spawning age, Sacramento River, winter-run Chinook salmon. Positive (+) nested PCR results are shown for kidney (K), posterior intestine (I), liver (L), gill (G), spleen (S), gonad (Go), heart (H) with resultant individual fish scores (IFS). Values in parentheses: single-round PCR results. Negative PCR and Gram-stain results are left blank. Data are for uninfected $(\mathrm{n}=5)$, low infection $(\mathrm{n}=7)$ and high infection $(n=8)$ fish, as determined by microscopic evaluation of Gram-stained impression smears from kidney tissues; scores are given for each fish. T: total

\begin{tabular}{|c|c|c|c|c|c|c|c|c|c|}
\hline Fish no. & Gram score & $\mathrm{K}$ & I & $\mathrm{L}$ & $\mathrm{G}$ & $\mathrm{S}$ & Go & $\mathrm{H}$ & IFS \\
\hline \multicolumn{10}{|l|}{ Uninfected } \\
\hline 1 & & & $(+)$ & $+(+)$ & & & & & $+(+)$ \\
\hline 2 & & & & & & & & & $0(0)$ \\
\hline 3 & & & & & & & & & $0(0)$ \\
\hline 4 & & & & & & & & & $0(0)$ \\
\hline 5 & & & & & & & & & $0(0)$ \\
\hline \multicolumn{10}{|l|}{ Low infection } \\
\hline 1 & 1 & + & + & + & $+(+)$ & & & + & $+(+)$ \\
\hline 2 & 1 & + & $+(+)$ & $+(+)$ & $+(+)$ & $+(+)$ & $+(+)$ & $+(+)$ & $+(+)$ \\
\hline 3 & 1 & $+(+)$ & $+(+)$ & $+(+)$ & $+(+)$ & $+(+)$ & $+(+)$ & $+(+)$ & $+(+)$ \\
\hline 4 & 2 & $+(+)$ & $+(+)$ & $+(+)$ & $+(+)$ & $+(+)$ & + & $+(+)$ & $+(+)$ \\
\hline 5 & 2 & + & $+(+)$ & + & & & + & & $+(+)$ \\
\hline 6 & 2 & $+(+)$ & $+(+)$ & $+(+)$ & & $+(+)$ & + & & $+(+)$ \\
\hline 7 & 2 & + & & & & & & & $+(0)$ \\
\hline $\mathbf{T}$ & $7 / 7$ & $7(3)$ & $6(5)$ & $6(4)$ & $4(4)$ & $4(4)$ & $5(2)$ & $4(3)$ & $7(6)$ \\
\hline \multicolumn{10}{|l|}{ High infection } \\
\hline 1 & 3 & $+(+)$ & $+(+)$ & $+(+)$ & $+(+)$ & $+(+)$ & & $+(+)$ & $+(+)$ \\
\hline 2 & 3 & $+(+)$ & $+(+)$ & $+(+)$ & $+(+)$ & $+(+)$ & $+(+)$ & $+(+)$ & $+(+)$ \\
\hline 3 & 3 & $+(+)$ & $+(+)$ & + & $+(+)$ & + & & & $+(+)$ \\
\hline 4 & 3 & $+(+)$ & $+(+)$ & $+(+)$ & $+(+)$ & $+(+)$ & $+(+)$ & & $+(+)$ \\
\hline 5 & 3 & + & $+(+)$ & $+(+)$ & $+(+)$ & $+(+)$ & & & $+(+)$ \\
\hline 6 & 3 & $+(+)$ & $+(+)$ & $+(+)$ & + & $+(+)$ & & + & $+(+)$ \\
\hline 7 & 4 & + & $+(+)$ & $+(+)$ & $+(+)$ & $+(+)$ & $+(+)$ & $+(+)$ & $+(+)$ \\
\hline 8 & 4 & $+(+)$ & $+(+)$ & $+(+)$ & $+(+)$ & $+(+)$ & + & + & $+(+)$ \\
\hline $\mathbf{T}$ & $8 / 8$ & $8(6)$ & $8(8)$ & $8(7)$ & $8(7)$ & $8(7)$ & $4(3)$ & $5(3)$ & $8(8)$ \\
\hline Total low + high & $15 / 15$ & $15(9)$ & $14(13)$ & $14(11)$ & $12(11)$ & $12(11)$ & $9(5)$ & $9(6)$ & $15(14$ \\
\hline
\end{tabular}

\section{DISCUSSION}

Fish infected with Sphaerothecum destruens frequently lack external or internal signs, and hence the parasite may go undetected until microscopic examination of tissue samples is conducted (Arkush et al. 1998). Current methods for detection are based on microscopic evaluation of stained (e.g. Giemsa, Gram) impression smears or stained histologic sections of affected organs. The organism can be difficult to identify in stained smears, particularly when present in low numbers. Histologic sections may be difficult to interpret because $S$. destruens can be confused with related organisms of the order Dermocystida with similar morphologic characteristics (Arkush et al. 2003). Additionally, this parasite is not easily identified by histologic methods unless there are lesions present consistent with longer-lived infections, and thus low-level infections in fish may go unrecognized (Arkush et al. 1998).

This report introduces the first PCR-based detection method for Sphaerothecum destruens. Related salmonid parasites of the class Mesomycetozoea
(Arkush et al. 2003) were tested using genomic DNA from these organisms and $S$. destruens-specific primers in single-round and nested PCR assays, and no amplification was recorded (Fig. 1). Using dilutions of purified spore genomic DNA derived from cell cultures as template, the nested PCR assay detected as little as $1 \mathrm{pg}$ (Fig. 2A), improving detection with single-round PCR by 1 order of magnitude (data not shown). The detection limit in this nested assay is slightly inferior to that in similar studies (Bell et al. 1999, Palenzuela et al. 1999). However, using purified $S$. destruens plasmid DNA, detection to $0.1 \mathrm{fg}$ of $S$. destruens-specific DNA was achieved using the nested assay (Fig. 2B). Unlike the studies of Andree et al. (1998) and Gonzalez et al. (2003), who reported that host DNA might be inhibitory, addition of fish DNA did not interfere with the threshold of detection reported here.

DNA extraction efficiency was limited to a minimum of 10 spores, comparable to results reported for Renibacterium salmoninarum (Chase \& Pascho 1998) and Listonella anguillarum (Gonzalez et al. 2003). This value was not consistently reproducible, however, and 
amplification failure between positive samples in the dilution series sometimes occurred. The parasite spores have a thick cell wall that is impervious to many DNA extraction methods, and the number of spores that eventually liberate DNA in the process may comprise a fraction of the total number of spores enumerated.

To evaluate the usefulness of this new detection method, 2 exposure experiments were conducted. In the first, juvenile Chinook salmon were given a single high dose of Sphaerothecum destruens spores in suspension by intraperitoneal injection, to provide 'known' infected subjects for subsequent PCR testing. The dose of $S$. destruens spores chosen for this study was based on earlier work in which microscopic examination of Gram-stained impression smears from the kidney revealed that a similar dose produced detectable infection in juvenile fish within 3 mo (Arkush et al. 1998). This dose was used to ensure detectable infection for comparative validation (Hiney \& Smith 1998) of the PCR method. Following this injection exposure, the nested PCR test amplified $S$. destruensspecific DNA in kidney tissue from $100 \%$ of experimentally infected fish $(n=83)$ at 1 and 3 mo postinjection, while single-round PCR and microscopic evaluation of stained kidney impression smears identified 79 of $83(95 \%)$ and 81 of $83(98 \%)$ positive fish, respectively (Table 1), resulting in 95 to $98 \%$ agreement between all 3 diagnostic methods. The Gram scores indicated a low degree of infection for most exposed fish sampled, although infection seemed to be progressing, since the Gram scores increased over time (Table 1).

In a second experiment, juvenile Chinook salmon were exposed to Sphaerothecum destruens spores by waterborne immersion and then maintained in the laboratory for up to $12 \mathrm{mo}$. Based on individual fish scores (IFS), the nested test identified 64 positive of 90 exposed fish $(71 \%$, ) while the single round test identified 38 positive fish ( $42 \%)$, all of which were also identified using the nested assay (Table 2). The single-round PCR test identified 15 positive organ samples that the nested test failed to detect. Overall, however, the nested PCR test identified positive samples from $30 \%$ of the total samples $(108 / 360)$ while the single-round test identified only $16 \%(57 / 360)$ (Table 2$)$.

The results of this experiment provide information on the distribution of the parasite in selected host tissues over time following a simulated natural exposure (Table 2). Using the nested assay, detection of parasitespecific DNA in $50 \%$ of the posterior intestine samples at the earliest time point (1 d p.e.) suggests passive collection of the parasite, presumably by consumption of water containing the parasite or even after temporary attachment to the buccal cavity, e.g. gill tissue, although the posterior intestine may also serve as a point of entry. Detection in this tissue dropped to $0 \%$ at 7 to $28 \mathrm{~d}$, then remained low (10 to $20 \%$ from $42 \mathrm{~d}$ to $6 \mathrm{mo})$, reaching a maximum of $40 \%$ at $12 \mathrm{mo}$. The persistence of parasite-specific DNA in the posterior intestine from $42 \mathrm{~d}$ to the end of the experiment suggests that parasite replication had occurred in this tissue, although detection in the total number of experimental samples was lower $(18 \%, 16 / 90)$ than in the gill $(47 \%$, $42 / 90)$ and kidney $(48 \%, 43 / 90)$ samples (Table 2). Increased detection of Sphaerothecum destruens in gill tissue over time (from $30 \%$ at $14 \mathrm{~d}$ to $80 \%$ at $28 \mathrm{~d}$ ) may be the result of parasite replication following initial attachment of a few spores. Similarly, detection of parasite DNA in the kidney increased over time, reaching $100 \%$ by 12 mo. $S$. destruens-specific DNA was detected less frequently in the liver, with an overall detection in 7 of 90 samples $(8 \%$, Table 2$)$. Increased detection of $S$. destruens-specific DNA in tissues over time is probably a combination of in situ replication and blood-borne dissemination of the parasite following initial infection, since the parasite can replicate in various cell types, including epithelial, mesenchymal and hematopoietic cells (Arkush et al. 1998). No parasite-specific DNA was detected in any of the control fish from either of the experimental transmission studies, suggesting that the PCR assay is not prone to identifying false-positives.

No fish died or showed clinical symptoms from infection following waterborne exposure. Mortality is infrequently observed in natural infections with Sphaerothecum destruens, and the onset of clinical disease may require extra stressors such as the physiological/ immunological changes experienced by smolting or spawning fish (Arkush et al. 2003). Gram scores from exposed fish indicated low levels of infection at 6 and 12 mo (Table 2). The nested PCR assay detected parasite-specific DNA in kidney from exposed fish sampled at all time points except at $7 \mathrm{~d}$ (frequencies ranged from 10 to $100 \%$ ), with an overall detection in 43 of 90 kidney samples $(48 \%)$, while microscopic evaluation of stained impression smears from the kidney identified S. destruens only in the latest time points ( 6 and $12 \mathrm{mo}$ ) with an overall detection in 14 of $90(16 \%)$ kidney samples (Table 2), demonstrating that the nested PCR test surpassed the limits of detection of the microscopic method when used to detect the parasite in fish with low infections.

In naturally infected broodstock fish, the nested PCR assay detected Sphaerothecum destruens-specific DNA in more tissues than the single-round test (Table 3). Parasite-specific DNA was amplified from these fish most often in the kidney, intestine and liver, followed by the gill and spleen, and then gonad and heart, in descending order (Table 3). Uninfected fish 
(based on microscopic examination of Gram-stained impression smears from kidney) were confirmed as negative using the PCR tests on DNA extracted from kidney tissue. However, in 1 adult broodstock fish (identified as negative based on analysis using both S. destruens-specific PCR on DNA from the kidney and microscopic evaluation of kidney tissue), S. destruensspecific DNA was detected in the liver and posterior intestine by PCR analysis (Table 3), suggesting that sampling from more than 1 organ may be necessary for increased accuracy in determining the presence/ absence of the pathogen.

Based on our findings, the kidney appears to be the best organ to sample for PCR-based detection of this parasite, since overall detection in this tissue ranged from 48 to $100 \%$ (Tables 1 to 3 ). Although not a focus of the present report, detection of the parasite in the blood (32\%) from the injection study and in the posterior intestine (18\%) and gill (47\%) from the immersion study suggests that blood (Gonzalez et al. 2003), posterior intestinal swabs (Fox et al. 2000) or gill biopsies (Martinelli-Liedtke et al. 1999) may be good candidates for non-lethal sample collection for detection of Sphaerothecum destruens in fishes.

DNA-based methodologies are becoming commonplace in laboratories, and the use of this PCR test for detection of Sphaerothecum destruens in fishes may save considerable time and expense for fish stock managers (Cunningham 2002). PCR amplification of S. destruens DNA from fish tissue samples does not infer clinical status of the fish or viability of the parasite material amplified (Hiney \& Smith 1998), but the information obtained, along with historical health information for a given population (e.g. suspected exposure to the parasite, infection or mortality rates) can be used to facilitate management decisions. Testing of water or sediment samples adjacent to captive fish populations could also be considered as part of a monitoring program for fish stocks (Hiney \& Smith 1998), as could analysis of potential intermediate hosts (although none are known for $S$. destruens).

The nested PCR assay described herein can be used alone as a diagnostic tool or in conjunction with histologic tests for confirmatory identification of the parasite, and shows promise for non-lethal analyses. Experimental transmission studies using juvenile fish show that the nested PCR test successfully detects Sphaerothecum destruens in fish tissue and can be used to identify early stages of infection. Further, results from waterborne transmission provide the first experimental evidence to support an earlier hypothesis on the pathogenesis of the disease (Arkush et al. 1998, 2003) that possible initial sites of attachment of the parasite may be the gill and/or posterior intestine, and that progression of infection immediately following exposure may be accomplished by replication of the parasite at these sites of attachment followed by blood-borne dissemination. Finally, detection of the parasite in tissues of naturally exposed adult fish using the nested PCR test demonstrates the versatility of this new methodology.

Acknowledgements. This research was conducted in collaboration with the US Fish and Wildlife Service and the California Department of Fish and Game under a permit from the National Marine Fisheries Service, and was supported by funds from the US Bureau of Reclamation and the California Department of Water Resources (contracts 4600001540 and 4600002737). We are grateful to P. Hershberger and R. Holt for kindly providing isolates of Ichthyophonus hoferi and Dermocystidium salmonis, respectively. R. Hedrick provided helpful discussions on experimental design. K. Andree helped with sequence alignment and initial primer design, and provided helpful technical advice. This is Contribution Number 2221, Bodega Marine Laboratory, University of California at Davis.

\section{LITERATURE CITED}

Andree KB, MacConnell E, Hedrick RP (1998) A nested polymerase chain reaction for the detection of genomic DNA of Myxobolus cerebralis in rainbow trout Oncorhynchus mykiss. Dis Aquat Org 34:145-154

Arkush KD, Frasca S Jr, Hedrick RP (1998) Pathology associated with the rosette agent, a systemic protist infecting salmonid fishes. J Aquat Anim Health 10:1-11

Arkush KD, Giese AR, Mendonca HL, McBride AM, Marty GD, Hedrick PW (2002) Resistance to three pathogens in the endangered winter-run chinook salmon (Oncorhynchus tshawytscha): effects of inbreeding and major histocompatibility complex genotypes.Can J Fish Aquat Sci 59:966-975

Arkush KD, Mendoza L, Adkison MA, Hedrick RP (2003) Observations on the life stages of Sphaerothecum destruens n. g., n. sp., a mesomycetozoean fish pathogen formally referred to as the rosette agent. J Eukaryot Microbiol 50(6):430-438

Bell AS, Yokoyama H, Aoki T, Takahashi M, Maruyama K (1999) Single and nested polymerase chain reaction assays for the detection of Microsporidium seriolae (Microspora), the causative agent of 'beko' disease in yellowtail Seriola quinqueradiata. Dis Aquat Org 37:127-134

Chase DM, Pascho RJ (1998) Development of a nested polymerase chain reaction for amplification of a sequence of the p57 gene of Renibacterium salmoninarum that provides a highly sensitive method for detection of the bacterium in salmonid kidney. Dis Aquat Org 34:223-229

Cunningham CO (2002) Molecular diagnosis of fish and shellfish diseases: present status and potential use in disease control. Aquaculture 206:19-55

Fox MD, Palenzuela O, Bartholomew JL (2000) Strategies for the diagnosis of Ceratomyxa shasta using the polymerase chain reaction: comparison of lethal and nonlethal sampling with microscopic examination. J Aquat Anim Health 12:100-106

Gonzalez SF, Osorio CR, Santos Y (2003) Development of a PCR-based method for the detection of Listonella anguillarum in fish tissues and blood samples. Dis Aquat Org 55: $109-115$ 
Grizzle JM, Altinok I, Noyes AD (2003) PCR method for detection of largemouth bass virus. Dis Aquat Org 54:29-33

Harrell LW, Elston RA, Scott TM, Wilkinson MT (1986) A significant new systemic disease of net-pen reared chinook salmon (Oncorhynchus tshawytscha) brood stock. Aquaculture 55:249-262

Hedrick RP, Friedman CS, Modin J (1989) Systemic infection in Atlantic salmon Salmo salar with a Dermocystidiumlike species. Dis Aquat Org 7:171-177

Hiney MO, Smith PR (1998) Validation of polymerase chain reaction-based techniques for proxy detection of bacterial fish pathogens: framework, problems and possible solutions for environmental applications. Aquaculture 162: $41-68$

Kerk D, Gee A, Standish M, Wainwright PO, Drum AS, Elston RA, Sogin ML (1995) The rosette agent of chinook salmon (Oncorhynchus tshawytscha) is closely related to choanoflagellates, as determined by the phylogenetic analyses of

Editorial responsibility: Carey Cunningham, Aberdeen, UK its small ribosomal subunit RNA. Mar Biol 122:187-192

Lannan CN, Winton JR, Fryer JL (1984) Fish cell lines: establishment and characterization of nine cell lines from salmonids. In Vitro 20:671-676

Martinelli-Liedtke TL, Shively RS, Holmberg GS, Sheer MB, Schrock RM (1999) Nonlethal gill biopsy does not affect juvenile chinook salmon implanted with radio transmitters. N Am J Fish Manag 19 (3):856-859

Miller KM, Withler RE, Beacham TD (1997) Molecular evolution at Mhc genes in two populations of chinook salmon Oncorhynchus tshawytscha. Mol Ecol 6:937-954

Palenzuela O, Trobridge G, Bartholomew JL (1999) Development of a polymerase chain reaction diagnostic assay for Ceratomyxa shasta, a myxosporean parasite of salmonid fish. Dis Aquat Org 36:45-51

Smith SA (2002) Nonlethal clinical techniques used in the diagnosis of diseases of fish. J Am Vet Med Assoc 1162: 1203-1206

Submitted: March 1, 2004; Accepted: June 3, 2004

Proofs received from author(s): October 12, 2004 